\title{
EQUESTRIAN TOURISM AS AN OFFER OF RURAL TOURISM - STUDY ON THE SELECTED EXAMPLES FROM PODKARPACKIE PROVINCE (POLAND) AND PREŠOV PROVINCE (SLOVAKIA)
}

MAŁGORZATA BUCZEK-KOWALIK, ${ }^{1}$ RAdOSLAV KLAMÁR, ${ }^{2}$ JÁN KOZOŇ ${ }^{3}$

\footnotetext{
${ }^{1}$ University of Rzeszow, POLAND

e-mail: malgorzatabuczek1@wp.pl

${ }^{2}$ University of Prešov, SLOVAKIA

e-mail: radoklamar@gmail.com

${ }^{3}$ University of Prešov, SLOVAKIA

e-mail: Jan.Kozon@statistics.sk
}

\begin{tabular}{l|l} 
RECEIVED & 28 April 2017 \\
ACCEPTED & 29 June 2017 \\
JEL & \\
CLASSIFICATION & Q26, Q10, R11
\end{tabular}

KEYWORDS

ABSTRACT equestrian tourism, rural areas, Poland, Slovakia

The aim of the study was to analyze the offer of equestrian tourism as one of leisure activities in rural areas in Poland and Slovakia.

The applied methodology included office and field methods. Office methods related to the analysis of source material - literature, maps, yearbooks and Internet resources. The field study consisted in carrying out observations and interviewing selected owners of the centers offering services in horse tourism.

The conducted analyses showed that both Podkarpackie Province and the Prešov Province have great potential for the development of equestrian tourism which advantages have not been fully exploited, particularly in Slovakia. These limitations are due to confusing legislature, the lack of cooperation between the various entities and poor promotion of this activity.

\section{Introduction}

Today tourism represents one of the most important leisure activities. It is a way to rejuvenate, relax, rest, encounter new people, culture and nature. 
Owing to their diversity, rural areas are particularly predisposed to the development of active forms of leisure. Agritourism centers and farms operating on those areas offer a variety of activities - walks in the countryside, cycling, canoeing and horse-riding trips.

According to lliev (2014) equestrian tourism is becoming increasingly popular in rural and semi-urban areas. On reason for this is that agritourism farms can jointly run horse tourism and agritourism. What is more, equestrian tourism in rural areas represents a rapidly growing trend of recreational and leisure activities for children, youth and adults.

The aim of the study was to analyze the functioning of equestrian tourism as one of the leisure activities offers in selected rural areas in Poland and Slovakia. The paper involved an attempt to answer the following research questions:

- what does affect the spatial differentiation of equestrian tourism centres?

- what is offered within equestrian tourism?

- what weaknesses, strengths, opportunities and threats are connected with the development of equestrian tourism?

\section{Study area}

The study area consists of two regions: Podkarpackie Province (Poland) and Prešov Province (Slovakia), which are characterized by similar social and natural environment. More than $52 \%$ of the population live in rural areas whereas the agricultural land have the largest share in the total area of the regions (Table 1).

Table 1. Characteristics of the analyzed regions

\begin{tabular}{lcc}
\hline \multicolumn{1}{c}{ Feature } & Podkarpackie Province & Prešov Province \\
\hline Surface area/km & 17,845 & 8,973 \\
Population [p/p] & $2,129,187$ & 820,697 \\
The share of the population in rural areas [\%] & 58.0 & 52.9 \\
The share of agricultural land [\%] & 52.5 & 42.0 \\
The rural or rural-urban communes [\%] & 90.0 & 96.5 \\
Marketability of agricultural production [\%] & 44.0 & 45.0 \\
\hline
\end{tabular}

Source: own work based on Mitura, Buczek-Kowalik (2016); Program hospodárskeho a sociálneho rozvoja...

The rural character of the study area is also determined by the prevalence of rural or rural-urban communes, low marketability of agricultural production and large agrarian fragmentation ( $85 \%$ of farms do not exceed the area of $5 \mathrm{ha}$ ). Due to the location in the foothills and mountain areas the conditions for agricultural development are difficult. The dominant crop is potatoes, while in livestock prevails cattle farming.

Both Podkarpackie Province and Prešov Province are characterized by varied terrain. According to the physical geographic regionalization by J. Kondracki (2014) Podkarpackie Province is situated within the three regions: Western Carpathians with the Podkarpackie region, Eastern Carpathians and the Polish highlands. Each of these regions is distinguished by a different geological structure, topography and diversity of wildlife.

The biggest advantage of the region is diverse flora and fauna which is unique in the country and thus protected. All terrain forms occupy a total area of $861,840.40$ ha, representing $44 \%$ of the entire region. 
According to Mazur and Lukniš's geomorphological regionalization (1986) Prešov Province belongs to the East and the West Carpathians, and only a small southern part to the Pannonian Basin.

Taking into account the criterion of development potential Michaeli, Ivanová (2005) divided Prešov Province into three regions: the lowland with great development potential; the basin region with great development potential and the mountain region with small potential. An important element of Prešov Province is rich and rather unspoilt nature. Protected areas constitute $17.8 \%$ of the province.

\section{Equestrian tourism in rurpal areas of Poland and Slovakia}

Since the 70s. of the twentieth century there can be observed a rapid growth in the world's interest in recreation activities in rural areas where tourists' needs to come in contact with nature, culture and practise forms of active recreation can be fully realized (Mika, 2007). According to Sikora (2012) the main reason for participating in tourism in rural areas is the juxtaposition of natural, anthropogenic attractions and tourism conditions of rural and forest areas with urban environment. From the point of view of the participants in tourist traffic this type of tourism includes various types of recreational and tourism activities, facilitating close encounters with nature and rural environment through hiking, cycling, horse riding, cross-country skiing, picking herbs, mushroom picking, sightseeing and educational trips (Sikora, 1999).

Equestrian (horse-riding) tourism, being a form of professional tourism, requires proper fitness and emotional training as well as suitable equipment and theoretical and practical instruction on how to act. It includes recreational horse riding in equestrian centers and in the field, short walks (lasting 1-4 hours, with the distance of 7-30 km), many hour trips (the distance of 30-70 km) and different horse riding rallies. What is more, horses can be used in hippotherapy, i.e. rehabilitation of disabled people with physical or mental injuries (Hollý, 2003; Kurek, Mika, Pitrus, 2007; Krzemień, 2002). Equestrian tourism opens possibilities of close encounters with nature, it meets the tourist's desire to test oneself, improves stamina and gives a lot of pleasure. It also makes tourists forget about the stress of everyday life, educates and develops personality (Merski, Warecka, 2009; lliev, 2014; Matlovicova, Klamár, Mika, 2015). Rural tourism and equestrian tourism represent the most expansive sort of advanced leisure recreation (lliev, 2014).

The surge in the interest in this form of activity has been witnessed in Poland and Slovakia since the beginning of the 90 s of the twentieth century. This period showed the increase in the number of riding schools and horse stables offering their clients various ways of spending time in the saddle. It is a relatively new, rapidly growing form of recreation, suitable for a wide group of clients (Lijewski, Mikułowski, Wyrzykowski, 2008; Špičáková 2009). Currently, in both Poland and Slovakia, many small private centers and agritourism farms are largely or mainly engaged in activities related in different ways to equestrian tourism. This concerns particularly the centers located near large cities (Kozak, 2013) or those in areas attractive for tourists (the Bieszczady or Beskid Mountains). Their offer also keeps developing, including, among others, horse riding lessons, horse riding in the field, rallies, show jumping, horse-drawn carriage rides, sleigh rides and skijoring behind a horse. Adults, children and adolescent can equally avail in this offer (Józefczyk, 2014; Špičáková, 2009). An important element in propagating this type of activity are horse picnics, festivals, equestrian events and Trec events (Korfel, Mastej, 2015). The increase in the interest in horse-riding market development offers great opportunities for the economy, e.g. through the development of the service and industry sector (blacksmithing, saddlery, production of fodder, horse-riding equipment or harnesses). 
Practising of equestrian tourism requires proper infrastructure, which means appropriately marked trails, signposts, information boards, stations (shelters) for riders and horses serving as resting places, sheds, benches, or camp grounds (Špičáková, 2009).

\section{Material and methods}

The paper used both cameral and field methods. At the cameral research stage, secondary materials (folders, brochures, guides, websites, event programs, scholarly and popular science publications) were used, and the obtained primary materials were analysed. During field works, pilot studies were performed, which involved freeform interviews based on a standardised list of required information with the owners of selected resorts providing equestrian tourism services. The 20 centers located in rural areas (10 in each Podkarpackie Province and Prešov Province) were selected based on their significance and position in the region, the availability and range of services offered. During the interview the centers operators were asked about their offer, the functioning of the centers, the main clients, additional sources of funding, opportunities and threats for the development of equestrian tourism in the regions concerned.

\section{Study pesullts}

Based on the analyses, it was found that in 2016 there were 79 and 36 centers of horse tourism in Podkarpackie Province and Prešov Province respectively (Figure 1).

These centers were distributed unevenly. Most equestrian centers in Poland are located around Rzeszow (in Rzeszow District) and in the Bieszczady Mountains (over 59\% of all centers), and the least of them are in the northern and north - eastern part of the province (Sandomierz Basin, Roztocze Upland). In the Prešov Province about $40 \%$ centers are located near Prešov - the capital of the region and the district towns of Poprad, Kezmarok, Bardejov and Vranov upon Toplou. Despite the favourable natural environment, in the eastern and south - east part, especially near the Polish border, there are no centers offering horse-riding (Figure 1). This is due, among others, to the lack of infrastructure facilitating development of tourism (accommodation, catering, entertainment).

Over $45 \%$ of all centers in Prešov Province and $65 \%$ centers in Podkarpackie Province are located in the areas of small towns with population up to 1,000 inhabitants.

Both on the Polish and Slovak sides there are centers with dozens of horses and small centers with only a few animal units in the herd.

Both on the Polish and Slovak sides the owners of horse riding schools are mainly individuals who have been pursuing their activities year-round for over 10 years. According to the owners, the greatest interest in horse riding can be observed in the summer months from July to September, and the lowest in the winter months from January to March.

The offer in equestrian tourism is also diversified. Most often the centers on the Polish and Slovak sides offer guided tours for children, horse riding lessons and excursions. Additionally, Podkarpackie centers offer multiday horse-riding rallies and even horse-riding expedition across the Polish border. Organized groups can take advantage of britzka rides, trapper carts or sleigh rides in the winter. For fans of extreme sports, some centers in the Bieszczady Mountains and near Prešov offer skijoring, i.e. skiing behind a horse and Trec classes. During the summer there are organized camps or day camps with horse-riding lessons, training in the rules of horse behaviour, etc. Another important activity is the use of horses in hippotherapy (mostly found in Podkarpackie Province). Apart 
from equestrian centres, "horseback recreational rides" in Podkarpackie Province are offered by equestrian agritourism farms located in places attractive to tourists, like in the Bieszczady and Lower Beskids foothills. Except for horse riding in indoor arenas or in the field, such farms additionally offer other attractions for children and adults, for example playing fields, playgrounds, barbecue areas or campfires.

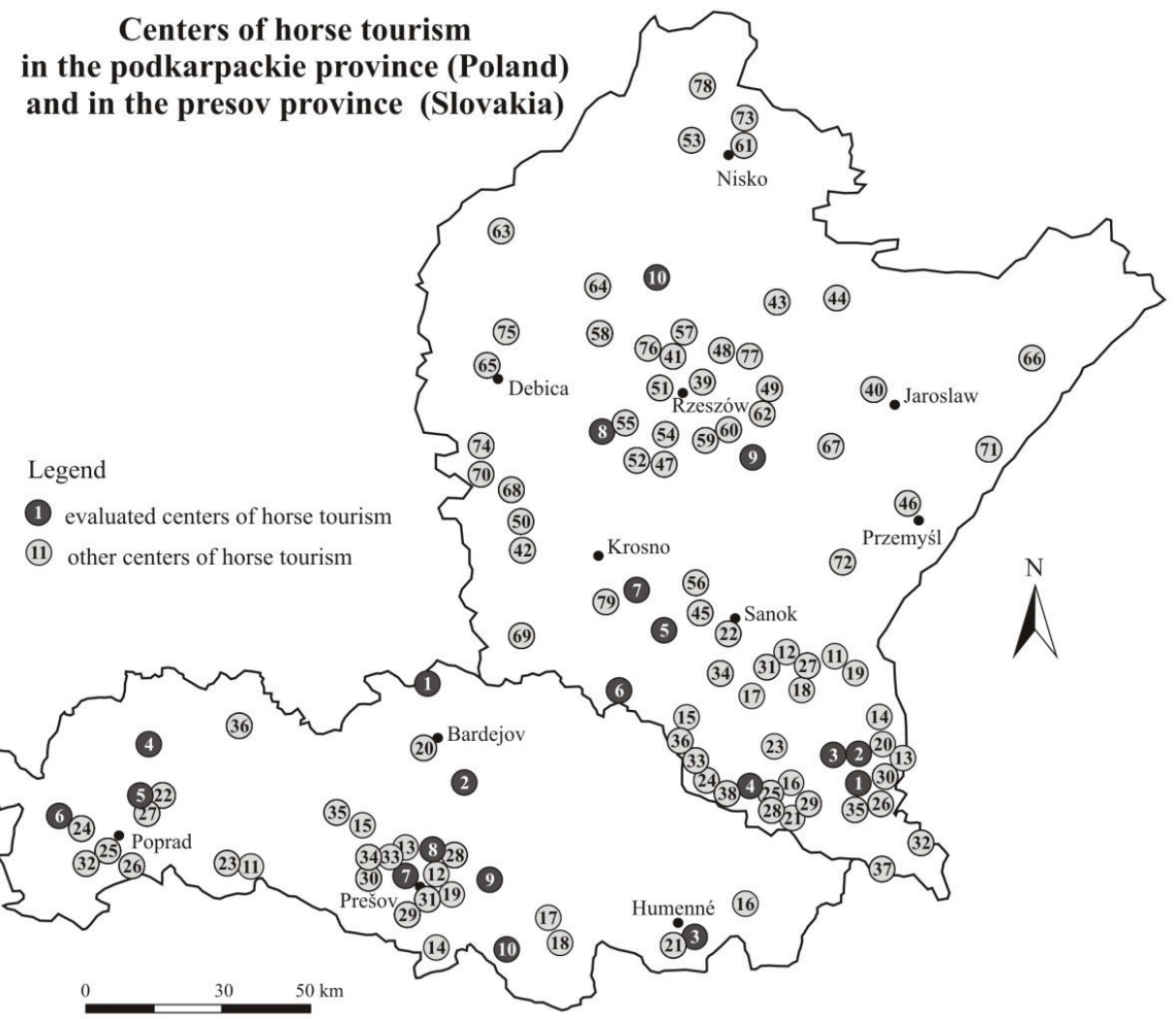

Figure 1. Centers of Equestrian Tourism in Podkarpackie Province and Prešov Province

Source: own elaboration.

More and more centers offer residence studs for horses as well as training and counselling in horse husbandry. This offer is more common among the centers in Podkarpackie Province.

An important element for the development of equestrian tourism is suitable infrastructure adapted for the rider and the horse. Within Podkarpackie Province horse riding trails are distributed unevenly. Most of the regionally and locally important trails are located in the southern part of the province in the Bieszczady and Low Beskids Mountain Ranges. In the area of Prešov Province there aren't any officially marked out horse riding trails. Individual operators engaged in organizing equestrian trips use hiking or partly biking trails or lead the group on unmarked trails. According to the owners of equestrian centers in Slovakia, there is a problem with the management of land 
areas on which the trails would run. Attempts at marking out horse riding trails are made as part of the cross-border projects.

Those tourists who do not ride horses can find in Podkarpackie Province many attractive "horse-related" events. The most important cyclical events include: e.g. Horse Fairs in Lutowiska, the Ascent and Descent of cattle and "Farewell to vacation with Hutsul horse" event in Rudawka Rymanowska (Jeździectwo..., 2014). The owners of the equestrian centres in Prešov Province pointed to the insufficient number of events, both occasional and regular, promoting equestrian tourism. The most important include, for example Day of St. Hubert near Vihorlat, Rodeo in Záhradné.

An important element supporting and promoting equestrian tourism on the Polish - Slovak border area are jointly implemented projects receiving funding from various sources. One of the most important projects was the creation of Polish-Slovak Equestrian Tourism Centre launched in years 2013-2014. The undertaken activities resulted in creating a cross-border, $210 \mathrm{~km}$ long equestrian and horse wagon trail (Projekt transgraniczny..., 2014).

During the interviews the owners of equestrian centers explained the limitations to the development of equestrian tourism (Table 2).

Table 2. SWOT analysis of the development of the equestrian tourism in the Podkarpackie Province and the Prešov Region

\begin{tabular}{|c|c|}
\hline Strengths & Weaknesses \\
\hline $\begin{array}{l}\text { - diverse topography, } \\
\text { - large share of grassland, } \\
\text { - landscape values, } \\
\text { - long horse-riding tradition, } \\
\text { - diverse offer, } \\
\text { - } \text { relatively low prices of the offered services }\end{array}$ & $\begin{array}{l}\text { - lack of cooperation between resorts and the local government, } \\
\text { - low promotion of equestrian tourism, } \\
\text { - vague legal regulations, } \\
\text { - low variety within the offer, } \\
\text { - high costs of running a business, } \\
\text { - bureaucracy, } \\
\text { - poorly developed infrastructure, } \\
\text { - low number of experts on horse breeding }\end{array}$ \\
\hline Opportunities & Threats \\
\hline $\begin{array}{l}\text { - availability of various funding sources, } \\
\text { - implementation of joint crossborder and regional projects, } \\
\text { - increase in the popularity of active forms of spending free time, } \\
\text { - extending and diversifying the equestrian tourism related offer, } \\
\text { - possibility to develop extra services related to visitor service }\end{array}$ & $\begin{array}{l}\text { - competition from the neighbouring countries, } \\
\text { - the residents' reluctance towards new undertakings }\end{array}$ \\
\hline
\end{tabular}

Source: own work based on interviews.

\section{Conclusions}

Both the Podkarpackie Province and the Prešov Region do have a long horse-riding tradition and a large potential (especially nature-related) in terms of the development of equestrian tourism.

An advantage of both regions are the landscape values, which result from the diverse natural environment.

An exceptionally significant aspect of the functioning of equestrian tourism, especially in the Podkarpackie Province, is the existing tourism infrastructure, which however should be improved and adapted to the specifics of equestrian tourism. 
The spatial differentiation of equestrian tourism centres in the Poland-Slovakia border areas does not result from the natural attractiveness as much as it is related to the proximity of big cities and potential consumers of this form of activity. This is particularly visible in the eastern and south-eastern parts of the Prešov Region where, despite the favourable natural environment conditions, there are no horse-riding centres. This is caused by, among other factors, the lack of infrastructure for the development of tourism (accommodation, boarding, entertainment).

In view of the findings obtained, it seems that an integral element of the development of equestrian tourism in the analysed areas is the necessity of collaboration between the centres, as well as with local governments and associations, which could contribute to the formation of a crossborder cluster promoting this form of activity.

Another significant aspect is the enhancement of promotional actions showing the advantages of the analysed regions as areas which are well conditioned for equestrian tourism. These actions should be complex, consistent and long-term, which implies e.g. establishing a development strategy for equestrian tourism or indicating its role in the existing strategic documents. Unfortunately, for neither the Podkarpackie Province nor the Prešov Region have such things been elaborated.

Other important elements include: undertaking innovative actions, extending the offer and adapting it for new groups of consumers (families with children, the elderly).

Easy access to reliable and up-to-date information is essential for the modern tourist, therefore it is necessary to create a uniform information system utilising new technologies (e.g. GPS). Such actions can be implemented within the frames of various crossborder cooperation projects funded by the European Union.

\section{References}

Hollý, K. (2003). Jezdecká turistika. Ostrava: Montanex.

Iliev, K. (2014). Rozwój turystyki konnej na obszarach wiejskich. Zeszyty Naukowe. Turystyka i Rekreacja, 2 (14), 181-190.

Jeździectwo. Radość. Pasja. Przygoda (2014). Rzeszów: Urząd Marszałkowski Województwa Podkarpackiego.

Józefczyk, M. (2014). Perspektywy rozwoju turystyki jeździeckiej w Polsce. Zeszyty Naukowe AWF Wrocław, 45, 138-145.

Kondracki, J. (2014). Geografia regionalna Polski. Warszawa: Wydawnictwo Naukowe PWN.

Korfel, A., Mastej, M. (2015). Górskie szaleństwo. Trec dla Ciebie! Gallop Koń i Jeździec, 3, 94-99.

Kozak, W. (2013). Turystyka jeździecka w Polsce: stan rzeczy, szanse i bariery wpływu na rozwój lokalny. Folia Turistica, 28, 205-224.

Krzemień, M.P. (2002). Spacery, wycieczki, rajdy. In: M.P. Krzemień (ed.), Górska turystyka jeździecka (pp. 75-79). Kraków: Ostoja.

Kurek, W., Mika, M., Pitrus, E. (2007). Formy turystyki kwalifikowanej. In: W. Kurek (ed.), Turystyka (pp. 256-278). Warszawa: Wydawnictwo Naukowe PWN.

Lijewski, T., Mikułowski, B., Wyrzykowski, J. (2008). Geografia turystyki Polski. Warszawa: PWE.

Matlovičová, K., Klamár, R., Mika, M. (2015). Turistika a jej formy. PreŠov.

Mazúr, E., Lukniš, M. (1986). Geomorfologické členenie SSR a ČSSR. Čast' Slovensko. 1 : 500,000. Bratislava: Slovenská kartografia.

Merski, J., Warecka, J. (2009). Turystyka kwalifikowana. Turystyka aktywna. Warszawa: AlmaMer.

Michaeli, E., Ivanová, M. (2005). Regionálna geoekologická štruktúra krajiny a primárny rozvojový potenciál Prešovského samosprávneho kraja. Folia Geographica, 8 (XLIII), 116-142.

Mika, M. (2007). Turystyka wiejska. In: W. Kurek (ed.), Turystyka (pp. 330-332). Warszawa: Wydawnictwo Naukowe PWN.

Mitura, T., Buczek-Kowalik, M. (2016). Zróżnicowanie oferty agroturystycznej w województwie podkarpackim. In: S. Graja-Zwolińska, A. Spychała, K. Kasprzak (eds.), Turystyka wiejska. Zagadnienie przyrodnicze i kulturowe. Tom II (pp. 53-62). Poznań: Wieś Jutra sp. z.o.o.

Sikora, J. (1999). Organizacja ruchu turystycznego na wsi. Warszawa: WSZiP. 
Sikora, J. (2012). Agroturystyka. Przedsiębiorczość na obszarach wiejskich. Warszawa: C.H. Beck.

Špičáková, H. (2009). Hipoturistika včera a dnes, tady a tam. In: Hipoturistika jako forma rekreace, lesni hospodáŕstvi, ochrana príirody, fakta a stŕety. Kostelec nad černými Lesy: Česká Lesnická Společnost.

Projekt transgraniczny PI-Sk (2014). Retrieved from: http://odrzechowa.com.pl/projekt/pol-slow/projekt_pol_slo.html\#pro (2.03.2107).

Program hospodárskeho a sociálneho rozvoja Prešovského samosprávneho Kraja na obdobie 2014-2020. Retrieved from: https:/l www.pokraj.sk/sk/samosprava/kompetencie-psk/regionalny-rozvoj/phsr-psk-2014-2020 (29.03.2017).

Cite this anticle aS: Buczek-Kowalik,M, Klamár, R., Kozoň, J. (2017). Equestrian tourism as an offer of rural tourism - study on the selected examples from Podkarpackie Province (Poland) and Prešov Province (Slovakia). European Journal of Service Management, 3 (23), 5-12. DOI: 10.18276/ejsm.2017.23-01. 